\title{
OPEN Author Correction: CancerTestis Antigen Promotes Triple Negative Breast Cancer Metastasis and is Traceable in the Circulating Extracellular Vesicles
}

\section{Anbarasu Kannan, Julie V. Philley, Kate L. Hertweck, Harrison Ndetan, Karan P. Singh, Subramaniam Sivakumar, Robert B. Wells, Ratna K. Vadlamudi id \& Santanu Dasgupta (i)}

Correction to: Scientific Reports https://doi.org/10.1038/s41598-019-48064-w, published online 12 August 2019

The original version of this Article contained a typographical error in the spelling of the author Subramaniam Sivakumar, which was incorrectly given as Subramanium Sivakumar. This has now been corrected in the PDF and HTML versions of the Article, and in the accompanying Supplementary Dataset file.

(c) (i) Open Access This article is licensed under a Creative Commons Attribution 4.0 International cc. License, which permits use, sharing, adaptation, distribution and reproduction in any medium or format, as long as you give appropriate credit to the original author(s) and the source, provide a link to the Creative Commons license, and indicate if changes were made. The images or other third party material in this article are included in the article's Creative Commons license, unless indicated otherwise in a credit line to the material. If material is not included in the article's Creative Commons license and your intended use is not permitted by statutory regulation or exceeds the permitted use, you will need to obtain permission directly from the copyright holder. To view a copy of this license, visit http://creativecommons.org/licenses/by/4.0/.

(C) The Author(s) 2020 